\title{
Push-pull Strategy with Trap Crops, Neem and Nuclear Polyhedrosis Virus for Insecticide Resistance Management in Helicoverpa armigera (Hubner) in Cotton
}

\author{
P. Duraimurugan and A. Regupathy \\ Department of Agricultural Entomology, Tamil Nadu Agricultural University \\ Coimbatore-641 003, India
}

\begin{abstract}
Insecticide resistance in Helicoverpa armigera (Hubner) is a major threat to cotton production in India. The virus infection was found to increase the susceptibility of $H$. armigera to the insecticides. But, use of Nuclear Polyhedrosis Virus (NPV) on a larger scale and on cotton due to leaf alkalinity poses certain practical problems. Hence, studies were carried out to assess the effects of push-pull strategy with trap crops, neem and NPV in cotton for the management of insecticide resistant $H$. armigera. Field experiments were conducted on cotton (MCU5) with trap crops (okra and pigeonpea) and neem was used to diversify the pests to trap crops whereby the control of these pests was assessed with the application of NPV. The preference of $H$. armigera was towards okra and pigeonpea as a trap crop compared to cotton. Application of NSKE on cotton diversified the $H$. armigera towards untreated okra and pigeonpea. Push-pull strategy with the conjunctive use of trap crops, restricted application of NSKE on cotton leaving trap crops and restricted application of NPV on trap crops was highly effective in reducing the incidence of $H$. armigera and damage to fruiting bodies, boll, locule and inter locule basis over cotton sole crop (untreated check). The percent recovery of NPV infected larvae varied from 37.5-47.5, 32.8-39.2 and 14.2-20.2\% on okra, pigeon pea and cotton respectively. The synthetic pyrethroids resistance in field survived $\mathrm{H}$. armigera at the end of the season was reduced from $87.5-93.1 \%$ to $76.4-84.3 \%$.
\end{abstract}

Key words: Insecticide Resistance Management, Helicoverpa armigera, Push-Pull Strategy, Cotton

\section{INTRODUCTION}

The cotton bollworm Helicoverpa armigera (Hubner) referred to as American bollworm, gram pod borer, tomato fruit borer holds the first rank amongst agricultural pests of both tropical and temperate countries of the world attacking a number of foods, subsidiary and cash crops including ornamental and medicinal plants ${ }^{[1]}$. Due to indiscriminate use of insecticides over several years, $H$. armigera has developed resistance to major insecticide groups used in India. In recent years, management of this pest has become increasingly difficult because of its development of resistance to most chemical insecticides commonly used in India ${ }^{[1-3]}$ and other parts of the world $^{[4,5]}$. The prevalence of high level of resistance to synthetic pyrethroids indicates an urgent need for implementation of curative Insecticide Resistance Management (IRM) for $H$. armigera. In this search, a new impetus with emphasis to cropping system, plant products and biocontrol agents is given to IRM. The exclusive use of cultural methods, botanicals and biocontrol agents were found to be less effective compared to an IPM approach in controlling $H$. armigera $^{[6]}$. The entomopathogenic infection viz., virus infection was found to increase susceptibility of $H$. armigera to the insecticides ${ }^{[7]}$. But, use of NPV on a larger scale and rapid inactivation of NPV on the cotton surface due to high leaf alkalinity ${ }^{[8-11]}$ poses certain practical problems. Significant beneficial effects can be obtained when cultural methods, botanicals and bio control agents were combined. Such approaches can be encapsulated in the "push- pull strategy" ${ }^{[12]}$ in which name products are deployed to 'push' colonizing insects away from cotton and also to conserve natural enemies. At the same time, the pests are aggregated on a sacrificial or trap crop, so that a selective control agent could be used effectively and economically to reduce the pest population. Keeping in view, detailed investigations were carried out under field conditions to evaluate the push-pull strategy for the conjunctive use of trap crops, neem and NPV for proper management of $H$. armigera in cotton under South Indian conditions.

\section{MATERIALS AND METHODS}

Two field experiments were conducted on cotton at Agricultural Research Station, Vaigaidam and

Corresponding Author: Dr.P. Duraimurugan, Department of Agricultural Entomology,

Tamil Nadu Agricultural University, Coimbatore - 641 003, India

E-mail: duraimuruganp@ rediffmail.com 
Agricultural Research Station, Bhavanisagar, Tamil Nadu Agricultural University, Tamil Nadu during Summer, 2003 (March-July). The experiments were laid out in a randomized block design with three variants viz., trap crops (okra/pigeon pea), Neem Seed Kernel Extract (NSKE5\%) spray restricted on cotton (MCU5) leaving trap crops and HaNPV restricted on trap crops leaving cotton. The experiment was replicated three times by maintaining a plot size of $10 \mathrm{~m} \times 10 \mathrm{~m}$. In each plot having 10 rows of cotton $(75 \times 30 \mathrm{~cm})$, fifth row was substituted with trap crops okra (Arka Anamika)/pigeon pea (APK 1), which was shown simultaneously on the other side of the ridge without any loss to cotton cropped area. The trap cropping system was compared with the cotton sole crop. All the plots received recommended agronomic practices of the region except the treatment operations. NSKE 5\% was applied to cotton leaving trap crops to diversify the pests to trap crops before each application of HaNPV formulations commencing from 46 Days After Sowing (DAS) at weekly interval up to the maturity phase (81 DAS). The HaNPV inoculum maintained in the Department of Agricultural Entomology, Tamil Nadu Agricultural University, Coimbatore was used in this study. The POBs were counted after diluting the samples 100-1000 folds ${ }^{[13]}$. The application of HaNPV formulations on trap crops/cotton sole crop (@ 500 LE) was commenced from one week after the application of NSKE spray (53 DAS) at weekly interval up to the maturity of the trap crop.

Assessment of Pests: The bollworm incidence was assessed on the basis of egg, larval population and percent damage on fruiting bodies (squares, flowers and bolls), open bolls, locules and inter locules. Eggs and larvae were counted on 10 randomly selected tagged plants per plot. The total number of fruiting bodies and those damaged by bollworms were counted at ten randomly selected plants per replication. The total number of bolls collected from ten randomly selected plants per plot at each picking was assessed for number of damaged bolls, number of locules damaged, inter locule boring and percentage was worked out. Kappas were picked out at ten day intervals from each plot and the yield was expressed in terms of $\mathrm{q} \mathrm{ha}^{-1}$.

Preference Ratio: In case of treatment involving trap crops, the Preference Ratio (PR) of pests on cotton and trap crops were worked out by using the following formula:

$\mathrm{PR}=\frac{\text { Population of pests on trap crop }}{\text { Population of pests on cotton }}$

Assessment of Effectiveness of NPV: The efficacy of HaNPV on trap crops/cotton was assessed by counting the total larval population and virosed larvae after respective treatment from ten randomly selected plants and the percent mortality was calculated.
Monitoring of Resistance Frequency in the Field Population of $\boldsymbol{H}$. armigera: The resistance frequency of F1 field population of $H$. armigera before first spray and F1 field survived population at the end of the crop to synthetic pyrethroids was monitored using Discriminating Dose (DD) assays and the percent resistance was calculated by using the formula given by Regupathy and Dhamu ${ }^{[14]}$.

\section{RESULTS AND DISCUSSION}

Effectiveness of Push-Pull Strategy Against $\boldsymbol{H}$. armigera in Cotton: Significant differences were observed in the incidence of $H$. armigera on cotton due to push-pull strategy with trap cropping, NSKE application on cotton and NPV application on trap crops. In cotton sole crop (untreated check), the mean egg and larval population at two locations was in the range of 31.3 to 32.2 and 27.1 to 30.3 per ten plants respectively and percent damage was in the range of 30.3 to $30.9,38.0$ to $40.0,27.0$ to 35.0 and 11.2 to 11.6 on fruiting bodies, boll, locule and inter locule basis respectively. The combined use of trap crops, application of NSKE on cotton and NPV on trap crops was superior in reducing the incidence of $H$. armigera and damage (Table 1 and 2). Among the treatments, cotton (NSKE treated) + okra (NPV treated) was superior and effected 58.5 to 66.5 and 69.4 to 78.9 percent reduction of eggs and larvae and 64.7 to 69.6 , 61.1 to $72.0,54.4$ to 74.6 and 27.6 to 27.7 percent reduction of fruiting bodies, boll, locule and inter locule damage respectively compared to cotton sole crop (untreated check). This was comparable with cotton (NSKE treated) +okra (NPV untreated) and cotton (NSKE treated) +pigeonpea (NPV treated). Cotton (NSKE treated)+okra (NPV untreated) treatment at two locations resulted in 64.5 to 69.3 and 64.6 to 76.9 percent reduction of eggs and larvae and 54.4 to $55.1,43.4$ to $64.8,48.5$ to 70.3 and 30.2 to 37.5 percent reduction of fruiting bodies, boll, locule and inter locule damage respectively. Considering the yield, cotton (NSKE treated) +okra (NPV treated) produced the highest yield of 16.0 to $18.3 \mathrm{q} \mathrm{ha}^{-1}$ followed by cotton (NSKE treated) tokra (NPV untreated) (14.5 to17. $\left.6 \mathrm{q} \mathrm{ha}^{-1}\right)$ and cotton (NSKE treated) + pigeon pea (NPV treated) (15.5 to $17.2 \mathrm{q}$ $\mathrm{ha}^{-1}$ ) compared to cotton sole crop (untreated check) ( 7.3 to $9.9 \mathrm{q} \mathrm{ha}^{-1}$ ).

The efficacy of other treatments in reducing the incidence and damage of $H$. armigera was found in descending order such as cotton (NSKE treated) + pigeon pea (NPV untreated) $\geq$ cotton sole crop (NSKE and NPV treated) $\geq$ cotton sole crop (NSKE treated) $>$ cotton (NSKE untreated) + okra (NPV treated) $\geq$ cotton $($ NSKE untreated $)+$ pigeon pea $($ NPV treated $)>$ cotton (NSKE untreated) + okra (NPV untreated) > cotton (NSKE untreated) + pigeon pea (NPV untreated) > cotton sole crop (NPV treated) $>$ cotton sole crop (untreated) (Table 1 and 2). 
Table 1: Effect of Push-pull Strategy with Conjunctive use of Trap Crops, Neem and HaNPV on Bollworm Incidence in Cotton (Vaigaidam,



Diversification of $\boldsymbol{H}$. armigera by Restricted Application of NSKE on Cotton towards Trap Crops: The oviposition preference of moths and feeding preference of larvae of $H$. armigera was towards okra and pigeonpea as a trap crop compared to cotton. The egg and larval preference towards cotton: okra varied from 1: 1.33-1: 1.55 and $1: 1.14-1: 1.31$ respectively and towards cotton: pigeon pea varied from 1:1.06-1:1.19 and 1:1.03-1:1.16, respectively. Application of NSKE on cotton leaving trap crops enhanced the diversion of $H$. armigera to untreated trap crops. The increased ratio of eggs and larvae towards cotton: okra varied from 1: 3.23 - 1: 3.45 and 1: 3.39-1: 3.41 , respectively and towards cotton: pigeon pea varied from 1: 2.04-1: 2.43 and 1: 2.34-1: 2.47, respectively (Table 3 ).

Effect of NPV Spray on Trap Crops and Cotton: The percent recovery of NPV infected larvae at two locations varied from 37.5-47.5, 32.8-39.2 and $14.2-20.2 \%$ on okra, pigeon pea and cotton in the respective treated plots (Table 4 ). 
Table 2: Effect of Push-pull Strategy with Conjunctive use of Trap Crops, Neem and HaNPV on Bollworm Incidence in Cotton (Bhavanisagar, Summer 2003)

\begin{tabular}{|c|c|c|c|c|c|c|c|}
\hline Treatments & $\begin{array}{l}\text { Mean no. } \\
\text { of eggs per } \\
10 \text { plants\# }\end{array}$ & $\begin{array}{l}\text { \% Reduction } \\
\text { over untreated } \\
\text { check }^{*}\end{array}$ & $\begin{array}{l}\text { Mean no. } \\
\text { of larvae per } \\
10 \text { plants\# }\end{array}$ & $\begin{array}{l}\% \text { Reduction } \\
\text { over untreated } \\
\text { check }^{*}\end{array}$ & $\begin{array}{l}\% \text { Damage } \\
\text { on fruiting } \\
\text { bodies* }\end{array}$ & $\begin{array}{l}\% \text { Reduction } \\
\text { over untreated } \\
\text { check }^{*}\end{array}$ & $\begin{array}{l}\% \text { Boll damage } \\
\text { (open boll } \\
\text { basis) } *\end{array}$ \\
\hline $\begin{array}{l}\text { Cotton (NSKE treated) + } \\
\text { okra (NPV treated) }\end{array}$ & $13.0(3.6)^{\mathrm{bc}}$ & $58.5(49.8)^{\mathrm{b}}$ & $8.3(3.0)^{\mathrm{a}}$ & $69.4(56.4)^{\mathrm{a}}$ & $9.2(17.6)^{\mathrm{a}}$ & $69.6(56.5)^{\mathrm{a}}$ & $14.8(22.5)^{\mathrm{a}}$ \\
\hline $\begin{array}{l}\text { Cotton (NSKE treated) + } \\
\text { okra (NPV untreated) }\end{array}$ & $11.1(3.3)^{\mathrm{a}}$ & $64.5(53.4)^{\mathrm{a}}$ & $9.6(3.2)^{\mathrm{ab}}$ & $64.6(53.4)^{\mathrm{c}}$ & $13.6(21.6)^{\mathrm{c}}$ & $55.1(47.9)^{\mathrm{c}}$ & $21.5(27.5)^{\mathrm{c}}$ \\
\hline $\begin{array}{l}\text { Cotton (NSKE untreated) + } \\
\text { okra (NPV treated) }\end{array}$ & $17.8(4.2)^{\mathrm{d}}$ & $43.1(41.0)^{\mathrm{d}}$ & $16.4(4.1)^{\mathrm{fg}}$ & $39.5(38.9)^{\mathrm{h}}$ & $17.9(25.0)^{\mathrm{d}}$ & $40.9(39.7)^{\mathrm{f}}$ & $28.0(31.9)^{\mathrm{e}}$ \\
\hline $\begin{array}{l}\text { Cotton (NSKE untreated) + } \\
\text { okra (NPV untreated) }\end{array}$ & $19.3(4.4)^{\mathrm{d}}$ & $38.3(38.2)^{\mathrm{e}}$ & $20.2(4.5)^{g}$ & $25.5(30.3)^{\mathrm{j}}$ & $21.5(27.6)^{\mathrm{ef}}$ & $29.0(32.6)^{\mathrm{h}}$ & $33.1(35.1)^{\mathrm{f}}$ \\
\hline $\begin{array}{l}\text { Cotton (NSKE treated)+ } \\
\text { pigeonpea (NPV treated) }\end{array}$ & $11.6(3.4)^{\mathrm{ab}}$ & $62.9(52.5)^{\mathrm{a}}$ & $8.9(3.1)^{\mathrm{a}}$ & $67.2(55.0)^{\mathrm{b}}$ & $11.7(19.9)^{\mathrm{b}}$ & $61.4(51.5)^{b}$ & $17.2(24.4)^{\mathrm{b}}$ \\
\hline $\begin{array}{l}\text { Cotton }(\mathrm{NSKE} \text { treated })+ \\
\text { pigeonpea (NPV untreated) }\end{array}$ & $13.8(3.7)^{\mathrm{c}}$ & $55.9(48.3)^{\mathrm{c}}$ & $10.8(3.4)^{\mathrm{bc}}$ & $60.2(50.8)^{\mathrm{d}}$ & $13.3(21.3)^{\mathrm{bc}}$ & $56.1(48.5)^{\mathrm{c}}$ & $22.1(28.0)^{\mathrm{cd}}$ \\
\hline $\begin{array}{l}\text { Cotton (NSKE untreated) + } \\
\text { pigeonpea (NPV treated) }\end{array}$ & $22.8(4.8) \mathrm{e}$ & $27.2(31.4)^{f}$ & $14.4(3.9)^{\mathrm{ef}}$ & $46.7(43.1)^{g}$ & $16.7(24.1)^{\mathrm{d}}$ & $44.9(42.0)^{\mathrm{e}}$ & $28.3(32.1)^{\mathrm{e}}$ \\
\hline $\begin{array}{l}\text { Cotton (NSKE untreated) + } \\
\text { pigeonpea (NPV untreated) } \\
\text { Cotton (NSKE and }\end{array}$ & $19.0(4.4)^{\mathrm{d}}$ & $39.3(38.8)^{\mathrm{e}}$ & $17.0(4.2)^{\mathrm{g}}$ & $37.3(37.6)^{\mathrm{i}}$ & $20.7(27.0)^{\mathrm{e}}$ & $31.7(34.2)^{\mathrm{g}}$ & $29.1(32.6)^{\mathrm{e}}$ \\
\hline NPV treated) & $14.0(3.8)^{\mathrm{c}}$ & $55.3(48.0)^{\mathrm{c}}$ & $11.5(3.5)^{\mathrm{cd}}$ & $57.6(49.3)^{\mathrm{e}}$ & $14.2(22.0)^{\mathrm{c}}$ & $53.1(46.8)^{\mathrm{d}}$ & $22.2(28.1)^{\mathrm{cd}}$ \\
\hline Cotton (NSKE treated) & $14.2(3.8)^{\mathrm{c}}$ & $54.6(47.6)^{\mathrm{c}}$ & $11.9(3.5)^{\mathrm{de}}$ & $56.1(48.5)^{\mathrm{f}}$ & $14.6(22.4)^{\mathrm{c}}$ & $51.8(46.0)^{\mathrm{d}}$ & $23.7(29.1)^{d}$ \\
\hline Cotton (NPV treated) & $30.4(5.5)^{\mathrm{f}}$ & $2.9(9.5)^{\mathrm{g}}$ & $21.6(4.7)^{\mathrm{h}}$ & $20.3(26.7)^{\mathrm{k}}$ & $23.1(28.7)^{\mathrm{f}}$ & $23.8(29.1)^{\mathrm{i}}$ & $35.2(36.3)^{\mathrm{g}}$ \\
\hline $\begin{array}{l}\text { Cotton sole crop } \\
\text { (untreated check) }\end{array}$ & $31.3(5.6)^{\mathrm{f}}$ & - & $27.1(5.2)^{\mathrm{i}}$ & - & $30.3(33.2)^{\mathrm{g}}$ & - & $38.0(38.0)^{\mathrm{g}}$ \\
\hline Treatments & $\begin{array}{l}\text { \% Reduction } \\
\text { over untreated } \\
\text { check* }^{*}\end{array}$ & $\begin{array}{l}\% \text { Locule } \\
\text { damage* }\end{array}$ & $\begin{array}{l}\% \mathrm{R} \\
\text { over } \\
\text { chec }\end{array}$ & $\begin{array}{l}\text { eduction } \\
\text { untreated } \\
\mathrm{k}^{*}\end{array}$ & $\begin{array}{l}\% \text { Inter } \\
\text { locule } \\
\text { damage* }\end{array}$ & $\begin{array}{l}\% \text { Reduction } \\
\text { over untreated } \\
\text { check* }\end{array}$ & $\begin{array}{l}\text { Kapas } \\
\text { yield }\left(\mathrm{q} \mathrm{ha}{ }^{-1}\right)\end{array}$ \\
\hline $\begin{array}{l}\text { Cotton (NSKE treated) + } \\
\text { okra (NPV treated) }\end{array}$ & $61.1(51.3)^{\mathrm{a}}$ & $12.3(20.5)$ & 54.4 & $(47.5)^{b}$ & $8.1(16.4)^{\mathrm{bcd}}$ & $27.7(31.7)^{\mathrm{e}}$ & $16.0^{\mathrm{a}}$ \\
\hline $\begin{array}{l}\text { Cotton (NSKE treated) + } \\
\text { okra (NPV untreated) }\end{array}$ & $43.4(41.2)^{\mathrm{c}}$ & $13.9(21.8)$ & 48.5 & $(44.1)^{\mathrm{c}}$ & $7.0(15.3)^{\mathrm{ab}}$ & $37.5(37.7)^{\mathrm{b}}$ & $14.5^{\mathrm{abc}}$ \\
\hline $\begin{array}{l}\text { Cotton (NSKE untreated) + } \\
\text { okra (NPV treated) }\end{array}$ & $26.3(30.8)^{\mathrm{e}}$ & $17.8(25.0)$ & 34.1 & $(35.7)^{\mathrm{f}}$ & $10.3(18.6)^{\mathrm{e}}$ & $8.0(16.4)^{\mathrm{h}}$ & $12.3^{\mathrm{cde}}$ \\
\hline $\begin{array}{l}\text { Cotton (NSKE untreated) + } \\
\text { okra (NPV untreated) }\end{array}$ & $12.9(21.0)^{\mathrm{g}}$ & $22.5(28.2)$ & 16.7 & $(24.0)^{\mathrm{g}}$ & $10.5(18.9)^{\mathrm{e}}$ & $6.3(14.4)^{\mathrm{i}}$ & $11.0^{\mathrm{e}}$ \\
\hline $\begin{array}{l}\text { Cotton (NSKE treated) + } \\
\text { pigeonpea (NPV treated) }\end{array}$ & $54.7(47.7)^{\mathrm{b}}$ & $10.6(18.9)$ & 60.7 & $(51.2)^{\mathrm{a}}$ & $6.1(14.1)^{\mathrm{a}}$ & $45.5(42.4)^{\mathrm{a}}$ & $15.5^{\mathrm{ab}}$ \\
\hline $\begin{array}{l}\text { Cotton }(\text { NSKE treated })+ \\
\text { pigeonpea (NPV untreated) }\end{array}$ & $41.8(40.3)^{\mathrm{c}}$ & $14.6(22.4)$ & 45.9 & $(42.6)^{d}$ & $7.8(16.1)^{\mathrm{abc}}$ & $30.4(33.4)^{\mathrm{d}}$ & $15.0^{\mathrm{ab}}$ \\
\hline $\begin{array}{l}\text { Cotton (NSKE untreated) + } \\
\text { pigeonpea (NPV treated) }\end{array}$ & $25.5(30.3)^{\mathrm{e}}$ & $18.4(25.3)$ & 31.9 & $(34.3)^{f}$ & $9.1(17.5)^{\text {cde }}$ & $18.8(25.6)^{\mathrm{f}}$ & $12.5^{\mathrm{cde}}$ \\
\hline $\begin{array}{l}\text { Cotton (NSKE untreated) + } \\
\text { pigeonpea (NPV untreated) } \\
\text { Cotton (NSKE and }\end{array}$ & $23.4(28.9)^{\mathrm{f}}$ & $22.3(28.1)$ & 17.4 & $(24.6)^{g}$ & $9.9(18.3)^{\mathrm{de}}$ & $11.6(19.9)^{\mathrm{g}}$ & $12.0^{\mathrm{de}}$ \\
\hline NPV treated) & $41.6(40.1)^{\mathrm{c}}$ & $14.5(22.2)$ & 46.7 & $(43.0)^{\mathrm{d}}$ & $6.9(15.2)^{\mathrm{ab}}$ & $38.4(38.2)^{\mathrm{b}}$ & $13.6^{\mathrm{a}-\mathrm{d}}$ \\
\hline Cotton (NSKE treated) & $37.6(37.8)^{d}$ & $15.4(23.0)$ & 43.0 & $(40.9)^{\mathrm{e}}$ & $7.3(15.6)^{\mathrm{abc}}$ & $34.8(36.1)^{\mathrm{c}}$ & $13.5^{\mathrm{bcd}}$ \\
\hline Cotton (NPV treated) & $7.4(15.7)^{\mathrm{h}}$ & $24.0(29.3)$ & 11.1 & $(19.4)^{\mathrm{h}}$ & $9.2(17.6)^{\mathrm{cde}}$ & $17.9(24.9)^{\mathrm{f}}$ & $9.0^{\mathrm{f}}$ \\
\hline $\begin{array}{l}\text { Cotton sole crop } \\
\text { (untreated check) }\end{array}$ & - & $27.0(31.3)$ & )$^{f}$ & & $11.2(19.4)^{\mathrm{e}}$ & - & $7.3^{g}$ \\
\hline
\end{tabular}

Effect of Trap Crops, Neem and NPV Spray Against Resistance Frequency of $\boldsymbol{H}$. armigera to Synthetic Pyrethroids: The percent resistance of field population of $H$. armigera to cypermethrin, fenvalerate, deltamethrin, lambda-cyhalothrin and beta-cyfluthrin was 91.4-91.6, 91.5-93.1, 88.0-92.3, 87.5-89.8 and $89.5-90.1 \%$ respectively. The percent resistance of the F1 field survival population after the last spray was 81.6-84.3, 80.4-82.0, 79.2-80.0, 76.4-79.0 and 76.9$80.0 \%$ to cypermethrin, fenvalerate, deltamethrin, lambda-cyhalothrin and beta-cyfluthrin, respectively (Table 5).
Cultural practices, resistance traits $^{[15]}$ and beneficial fauna activity ${ }^{[16]}$ make it possible to reduce the damage caused by pest complex, but it is not enough to maintain the economic sustainability of the cotton crop $^{[17]}$. Diversification of crop ecosystem in many cases results in reduced pest infestation ${ }^{[18]}$. Botanicals are finding more effective against many lepidopterans ${ }^{[19]}$ and also found that there was no sign of the insects developing any resistance against botanicals ${ }^{[20]}$, probably because, it contains a number of complex phytochemicals instead of a single active principle as in the case of insecticides. 
American J. Applied Sci., 2 (6): 1042-1048, 2005

Table 3: Effect of Trap Crops and Restricted Application of NSKE on Cotton on the Preference of Helicoverpa armigera (Summer, 2003)

\begin{tabular}{|c|c|c|c|c|c|c|c|c|c|c|}
\hline \multirow[b]{3}{*}{ Cropping system } & \multirow{3}{*}{$\begin{array}{l}\text { NSKE 5\% spray } \\
\text { on cotton }\end{array}$} & \multirow[b]{3}{*}{ Crops } & \multicolumn{4}{|c|}{ Vaigaidam } & \multicolumn{4}{|c|}{ Bhavanisagar } \\
\hline & & & \multicolumn{2}{|l|}{ Eggs } & \multicolumn{2}{|c|}{ Larvae } & \multicolumn{2}{|l|}{ Eggs } & \multicolumn{2}{|l|}{ Larvae } \\
\hline & & & $\mathrm{P}$ & PR & $\mathrm{P}$ & $\mathrm{PR}$ & $\mathrm{P}$ & PR & $\mathrm{P}$ & PR \\
\hline \multirow[t]{4}{*}{ Cotton + Okra } & \multirow{2}{*}{$\begin{array}{l}\text { Cotton untreated } \\
\text { with NSKE }\end{array}$} & Cotton & 18.91 & - & 18.81 & - & 19.33 & - & 20.18 & - \\
\hline & & Okra & 29.44 & $1: 1.55$ & 21.55 & $1: 1.14$ & 25.8 & $1: 1.33$ & 26.55 & $1: 1.31$ \\
\hline & \multicolumn{2}{|c|}{ Cotton treatedCotton } & 9.91 & - & 7 & - & 11.08 & - & 9.63 & - \\
\hline & with NSKE & Okra & 34.22 & $1: 3.45$ & 23.88 & $1: 3.41$ & 35.8 & $1: 3.23$ & 32.66 & $1: 3.39$ \\
\hline \multirow[t]{4}{*}{ Cotton + Pigeonpea } & \multirow{4}{*}{$\begin{array}{l}\text { Cotton untreated } \\
\text { with NSKE } \\
\text { Cotton treated } \\
\text { with NSKE }\end{array}$} & Cotton & 20.91 & - & 19.18 & - & 19 & - & 17 & - \\
\hline & & Pigeonpea & 22.33 & $1: 1.06$ & 19.9 & $1: 1.03$ & 22.66 & $1: 1.19$ & 19.72 & $1: 1.16$ \\
\hline & & Cotton & 11.75 & - & 10.54 & - & 13.75 & - & 10.81 & - \\
\hline & & Pigeonpea & 24 & $1: 2.04$ & 24.72 & $1: 2.34$ & 33.5 & $1: 2.43$ & 26.72 & $1: 2.47$ \\
\hline \multirow[t]{2}{*}{ Cotton sole crop } & $\begin{array}{l}\text { Cotton untreated } \\
\text { with NSKE }\end{array}$ & Cotton & 32.16 & - & 30.27 & - & 31.33 & - & 27.09 & - \\
\hline & $\begin{array}{l}\text { Cotton treated } \\
\text { with NSKE }\end{array}$ & Cotton & 19.41 & - & 12.45 & - & 14.24 & - & 11.9 & - \\
\hline
\end{tabular}

P-Mean population per ten plants

PR-Preference ratio

Table 4: Effect of HaNPV Spray on Trap Crops and Cotton (Summer 2003)

\begin{tabular}{llll} 
& & \\
Treatments & & Percent NPV infected larvae on trap crops/cotton \\
\hline Cotton (NSKE treated) + Okra (NPV treated) & Trap crop/cotton & Vaigaidam & Bhavanisagar \\
Cotton (NSKE treated) + Okra (NPV untreated) & Okra & $38.5(38.1)^{\mathrm{b}}$ & $41.4(40.0)^{\mathrm{a}}$ \\
Cotton (NSKE untreated) + Okra (NPV treated) & Okra & $1.0(4.9)^{\mathrm{f}}$ & $1.1(6.2)^{\mathrm{f}}$ \\
Cotton (NSKE untreated) + Okra (NPV untreated) & Okra & $47.5(43.5)^{\mathrm{a}}$ & $37.5(37.7)^{\mathrm{bc}}$ \\
Cotton (NSKE treated) + Pigeonpea (NPV treated) & Okra & $1.4(6.6)^{\mathrm{f}}$ & $1.2(6.3)^{\mathrm{f}}$ \\
Cotton (NSKE treated) + Pigeonpea (NPV untreated) & Pigeonpea & $36.2(37.0)^{\mathrm{b}}$ & $39.2(38.7)^{\mathrm{b}}$ \\
Cotton (NSKE untreated) + Pigeonpea (NPV treated) & Pigeonpea & $0.6(4.6)^{\mathrm{f}}$ & $1.0(5.6)^{\mathrm{fg}}$ \\
Cotton (NSKE untreated) + Pigeonpea (NPV untreated) & Pigeonpea & $32.8(34.9)^{\mathrm{c}}$ & $36.7(37.3)^{\mathrm{c}}$ \\
Cotton (NSKE and NPV treated) & Pigeonpea & $0.4(4.9)^{\mathrm{f}}$ & $0.3(3.4)^{\mathrm{h}}$ \\
Cotton (NSKE treated) & Cotton & $14.2(22.1)^{\mathrm{e}}$ & $20.2(26.7)^{\mathrm{d}}$ \\
Cotton (NPV treated) & Cotton & $0.7(5.8)^{\mathrm{f}}$ & $1.6(5.5)^{\mathrm{fg}}$ \\
Cotton sole crop (untreated check) & Cotton & $19.0(25.8)^{\mathrm{d}}$ & $15.3(23.0)^{\mathrm{e}}$ \\
\hline Fites & Cotton & $0.9(5.5)^{\mathrm{f}}$ & $0.7(4.9)^{\mathrm{g}}$
\end{tabular}

Figures in parentheses are arcsine transformed values

Means in a column followed by the same letter(s) are not significantly different $(\mathrm{P}=0.05)$ by DMRT

Table 5: Effect of Push-pull Strategy with Conjunctive use of Trap Crops, Neem and HaNPV Against Resistance Frequency (RF) of H. armigera to Synthetic Pyrethroids (Summer 2003)

\begin{tabular}{|c|c|c|c|c|c|}
\hline \multirow[b]{3}{*}{ Synthetic Pyrethroids } & \multirow[b]{3}{*}{ DD dose $\left(\mu \mathrm{g} \mu \mathrm{L}^{-1}\right)$} & \multicolumn{4}{|c|}{$\%$ Resistance $\pm \mathrm{SE}$} \\
\hline & & \multicolumn{2}{|c|}{$\begin{array}{l}\% \text { Resistance of } F_{1} \text { field population } \\
\text { before first spray }\end{array}$} & \multicolumn{2}{|c|}{$\begin{array}{l}\% \text { Resistance of } F_{1} \text { field survived population } \\
\text { after last spray }\end{array}$} \\
\hline & & Vaigaidam & Bhavanisagar & Vaigaidam & Bhavanisagar \\
\hline Cypermethrin & 0.1 & $91.4 \pm 3.7$ & $91.6 \pm 4.0$ & $81.6 \pm 5.6$ & $84.3 \pm 5.1$ \\
\hline Fenvalerate & 0.2 & $93.1 \pm 3.4$ & $91.5 \pm 3.6$ & $82.0 \pm 5.5$ & $80.4 \pm 5.9$ \\
\hline Deltamethrin & 0.0125 & $92.3 \pm 3.7$ & $88.0 \pm 4.6$ & $79.2 \pm 4.8$ & $80.0 \pm 5.7$ \\
\hline Lambda -cyhalothrin & 0.025 & $87.5 \pm 4.5$ & $89.8 \pm 3.9$ & $76.4 \pm 5.7$ & $79.0 \pm 5.6$ \\
\hline Beta-cyfluthrin & 0.2 & $89.5 \pm 4.1$ & $90.1 \pm 4.2$ & $80.0 \pm 5.2$ & $76.9 \pm 5.9$ \\
\hline
\end{tabular}

SE- Pooled binomial standard error $( \pm)$

Biological control of the IRM / IPM system is a subject of considerable current interest because of a perceived urgency to develop and adopt safe and efficient methods for managing agricultural pests ${ }^{[21]}$. However, the exclusive use of biocontrol agents like NPV against $H$. armigera were found to be less effective compared to integrated pest approach ${ }^{[6]}$. Inactivation of NPV due to high $\mathrm{pH}$ values of dew on cotton foliage ${ }^{[9-11,22]}$ is the major constraint in cotton ecosystem. However the above difficulties could be overcome through a concept called push-pull strategy ${ }^{[23,24]}$. Two field trials were conducted with the conjunctive use of three components such as trap crops, neem spray on cotton alone along with restricted application of NPV on trap crops against $H$. armigera. Push-pull strategy with the conjunctive use of trap crops (Okra/pigeon pea), NSKE application on cotton and NPV application on trap crops significantly reduced the incidence of $H$. armigera.

The diverse biological effects of neem are repellent, phagodeterrence, growth inhibition, abnormal development and oviposition suppression ${ }^{[25-31]}$. In South India, use of okra, castor, marigold, Nicotiana rustica and coriander as trap crops are recommended for the 
control of $H$. armigera and other pests of cotton ${ }^{[1]}$. In the present study, okra acted as a good trap for $H$. armigera and the efficiency of the trap crop was improved by applying NSKE on cotton. Similar diversion of A. devastans, B. tabaci, A. Gossip and semi Loopers from cotton to okra ${ }^{[32]}$ was observed when the non-edible oil formulations were applied to the main crop. Spraying of NPV on trap crops leaving cotton efficiently checked the population of $H$. armigera. The effective control of larvae on okra with NPV is in conformity with observations made by Praveen ${ }^{[33]}$. The ineffectiveness of HaNPV on cotton particularly on variety MCU 5 is in accordance with the report by Rabindra et al. ${ }^{[34]}$.

On the conjunctive use of trap crops, NSKE on cotton and NPV on trap crops, the resistance of the field collected population of $H$. armigera to the pyrethroids monitored through discriminating dose showed lesser percent survival compared to the survival of the field collected population before spraying. This might be due to the NPV infection of $H$. armigera collected from the field sprayed with NPV. Under laboratory conditions, it was observed the field collected larvae showed NPV contamination even in the subsequent generation. The carry over of diseases through adults plays important role in the vertical transmission of the virus over generations $^{[35,36]}$. Botanicals may be used to increase the susceptibility of the target pest. The exposure to a stressor might influence the susceptibility of the host to an active pathogen. The biologically active compounds from the plant products penetrate the gut wall which allows the easy penetration of the pathogen into the haemocoel $^{[37]}$.

The non-chemical methods used in the present study in cotton provides scope for relaxation in selection pressure of $H$. armigera to certain extent. More over these botanical pesticides do not kill the pest immediately and it leaves the vulnerable population to the natural enemies keeps the continuous presence of the natural enemies which take care of the residual population which is an important step in cotton IPM. The combined use of botanicals with microbial pesticides and chemical insecticides increases the efficacy and also reduces the cost per application and delay the development of resistance.

\section{ACKNOWLEDGEMENT}

The financial support from the Common Fund for Commodities (CFC) Europe, International Cotton Advisory Committee (ICAC) U.S.A and Natural Resource Institute (NRI), U.K. is acknowledged.

\section{REFERENCES}

1. K. Kranthi, J. Singh, A. Iqabal, Y.Wu and D.A. Russell, 2004. Patterns and Magnitude of insectivore resistance levels in India, Pakistan and
China. In: Biljon J.V. and D. Joubert (Eds.) Proc. World Cotton Conference III, 9-13, March, Cape Town, South Africa, pp: 1215 -1229.

2. Armes, N.J., S.K. Banerjee, K.R. De Souza, D.R. Jadhav, A.B.S. King, K.R. Kranthi, A. Regupathy, T. Surilivelu and N. Venugopal Rao, 1994. Insecticide resistance in Helicoverpa armigera in India: Recent Developments. In: Proc. Brighton Crop Prot. Conf., pp: 437-442.

3. Regupathy, A., D. Jadhav, S.K. Kapoor, D. Singh, K. Kranthi and D. Russel, 1998. Patterns of insecticide cross resistance in Helicoverpa armigera and Bemisia tabaci in India. In: Newfrontiers in Cotton Research: World Cotton Res. Conf 2., 6-12, Sep., Athens, Greece. Abst., pp: 178.

4. Gunning, R.V., C.S. Easton, L.R. Greenup and V.E. Edge, 1984. Pyrethroid resistance in Heliothis armigera (Hubner) (Lepidoptera: Noctuidae) in Australia. J. Econ. Entomol., 77: 1283-1287.

5. Martin, T., G. O. Chou, F. Hala N'Klo, J.M. Vassal and M. Vaissayre, 2000. Helicoverpa armigera (Hubner), in West Africa, Pest Mgmt. Sci., 56: 549-554.

6. Tanweer, A. and L.N. Rao, 1997. Evaluation of certain integrated pest management components for management of white fly and American bollworm of cotton. Pestology, 21: 47-52.

7. Leethial, R.P. and A. Regu pathy, 2004. Biological suppression of synthetic pyrethroids resistance in Helicoverpa armigera (Hubner) by nuclear polyhedrosis viruses (HaNPV). In: $15^{\text {th }}$ Intl. Plant Protection Congress, 6-11, July, Beijing, China. Abst., pp: 254.

8. Ignoffo, C.M., 1966. Effects of age on mortality of Heliothis Zea and Heliothis virescens larvae exposed to a nuclear polyhedrosis virus. J. Invert. Pathol., 8: 279-282.

9. Gudauskas, R.T. and D. Canerday, 1968. The effect of heat, buffer salts and $\mathrm{H}$-ion concentration and ultraviolet light on the infectivity of Heliothis and Trichoplusia nuclear polyhedrosis viruses. J. Invert. Pathol., 12: 405-411.

10. Young, S.Y. and W. C. Yearian, 1977. Effect of dew from cotton and soybean foliage on activity of Heliothis nuclear polyhedrosis virus. J. Invert. Pathol., 29: 105-114.

11. Mcleod, P.J., W.C. Yearian and S.Y. Young, 1977. Inactivation of Baculovirus Heliothis by ultraviolet irradiation, dew and temperature. J. Invert. Pathol., 30: 237-241.

12. Pickett, J.A., G.R. Cayley, G.W. Dawson, D.C. Griffths, S.H. Hockland, B. Marples, R.T. Plumb and C.M. Woodcock, 1986. Use of the alarm pheromone and derivatives against aphid mediated damage. In: $6^{\text {th }}$ Intl. Congress Pesticide Chemistry, IUPAC, Ottawa, pp: 20-28. 
13. Evans, H.F. and M. Shapiro, 1997. Viruses. In: L. Lacey (Ed.) Manual of Techniques in Insect Pathology. Academic Press, London, pp: 17-54.

14. Regupathy, A. and K.P. Dhamu, 2001. Statistics Workbook for Insecticide Toxicology. softeck Computers, Coimbatore, pp: 206.

15. Sadras, V.O., 1995. Compensatory growth in cotton after loss of reproductive organs. Field Crops Res., 40: 1-18.

16. Wilson, L.J., G.P. Fitt and R.K. Mensah, 1998. INGARD cotton-its role in cotton IPM. In: Pest Management-Future Challenges. Proc. Of the $6^{\text {th }}$ Australian Applied Entomology Conference. Zalucki, M.P., R.A.I. Drew and G.G. White (Eds.). Uni. Qld Press, Brisbane, pp: 267-276.

17. Khadi, B.M., V.N. Kulkarni, I.S. Katageri and H.M. Vamadevaiah, 2001. Role of transgenic in improving quality and quantity of cotton. Nat. J. Plant Improvement, 3: 11-23.

18. Altieri, M.A. and D.K. Letourneau, 1982. Vegetation management and biological control in agro ecosystems. Crop. Protect., 1: 405-430.

19. Regupathy, A. and R. Ayyasamy, 2004. Formulations of botanical pesticide. In: Proc. National Symposium on Green Pesticide for Insect Pest Management. 5-6, Feb., Loyola College, Chennai. Abst., pp: 5.

20. Vollinger, M., 1987. The Possible Development of Resistance Against Neem Seed Kernel Extract and Deltamethrin in Plutella xylostella. In: Schmutterer M. and K.R.S Ascher. (Eds.) Natural Pesticides From the Neen Tree and Other Tropical Plants. CRC Press, Baco Raton, lorida, India, pp: 543-554.

21. Balasubramanian, G., 2001. Interaction of Microbials with Entomophages. In: Microbial Control of Crop Pests. Rabindra, R.J., J.S. Kennedy, N. Sathiah, B. Rajasekaran and M.R. Srinivasan. (Eds.), Tamil Nadu Agric. University, Coimbatore, India.

22. Ignoffo, C.M., J.R. Bradeey, F.R. Gilliland, F.A. Harris, L.A. Falcon, L.V. Larson, R.L. McGorr, P.P. Sikorowski, T.F. Watson and W.C. Yearian, 1972. Field studies on the stability of the Heliothis nucleo-polyhedrosis virus at various sites through the cotton belt. Environ. Entomol., 1: 385-390.

23. Pyke, B., M. Rice, B. Sabine and M. Zalucki, 1987. The push-pull strategy-behavioral control of Heliothis. In: Workshop on Australian Cotton Grower, Australia, pp: 7-9.

24. Miller, J.R. and R.S. Cowles, 1990. Stimulus deterrent diversionary cropping: A concept and its possible application to onion maggot control. J. Chem. Ecol., 16: 3197-3212.

25. Rembold, H., G.K. Sharma, C.H. Czoppelt and H. Schmutterer, 1980. Evidence of growth disruption in insects without feeding inhibition by neem seed fractions. Z. P. flkrankh. P. flschutz, 87: 290-297.
26. Joshi, B.G. and S. Sitharamaiah, 1979. Neem kernel as an ovipositional repellent for Spodoptera litura (F.) Moth. Phytoparasitica, 7: 199-202.

27. Blaney, W.M., M.S.J. Simmonds, S.V. Ley, J.C. Anderson and P.L. Toogood, 1990. Antifeedant effects of azadirachtin and structurally related compounds on lepidopterous larvae. Entomol. Exp. Appl., 55: 149-160.

28. Rice, M., 1993. Built-in Resistance Prevention (BIRP): A valuable property of azadirachtin. In: World Neem Conf., Bangalore, India, Abstr., pp: 13-14.

29. Sinha, S.N. and K.N. Mehrotra, 1988. Diflubenzuron and neem (Azadirachta indica) oil in control of Heliothis armigera infesting chickpea (Cicer arietimum). Indian J. Agric. Sci., 58: 238-239.

30. Kirsch, K., 1987. Studies of the efficacy of neem extract in controlling major insect pests in tobacco and cabbage. In: Proc. $3^{\text {rd }}$ Int. Neem Conf., Nairobi, Kenya. pp: 495-515.

31. Simmonds, M.S.J., W.M. Blaney, S.V. Ley, J.C. Anderson and P.L. Toogood, 1990. Azadirachtin: Structural requirements for reducing growth and increasing mortality in lepidopterous larvae. Entomol. Exp. Appl., 55: 169-181.

32. Saminathan, V.R. and A. Regupathy, 2003. Conjunctive use of okra as trap crop and plant products for the management of early season pests of cotton. In: Proc. National Symposium on Sustainable Insect Pest Management, 6-7, Feb., Entomology Research Institute, Loyola College, Chennai. Abst., pp: 36.

33. Praveen, P.M., 2000. Eco-friendly management of major pests of okra (Abelmoschus esculentus L.) and tomato (Lycopersicon esculentum Mill.). M.Sc. (Ag.) Thesis, Tamil Nadu Agric. University, Coimbatore, India, pp: 16.

34. Rabindra, R.J., M. Muthusami and S. Jayaraj, 1994. Feasibility of nuclear polyhedrosis virus and Chrysoperla carnea Stephen use in Helicoverpa armigera (Hubner) management on chickpea. Pest Mgmt Econ. Zool., 2: 31-34.

35. Nair, K.P.V. and A. Jacob, 1985. Transmission of nuclear polyhedrosis virus of rice swarming caterpillar, Spodoptera mauritia (Boisduval) through egg. Entomon., 10: 1-6.

36. Subramanian, 2003. Studies on the use of baculoviruses for the management of Plutella xylostella (L.) and Spodoptera litura (F.) Infesting cauliflower. Ph.D. Thesis, Tamil Nadu Agric. University, Coimbatore, India.

37. Steinhaus, E.A., 1963. Insect Pathology: An Advanced Treatise, Acad. Press, New York. 